\title{
In Situ Investigation of Oxidation of Aluminum Alloy Powders with Calcium and Barium by Synchrotron Radiation
}

\author{
Vladimir G. Shevchenko, Danil A. Eselevich", Alexey I. Ancharov, Boris P. Tolochko \\ Institute of Solid State Chemistry, Russian Academy of Sciences, Russia
}

Copyright $(2017$ by authors, all rights reserved. Authors agree that this article remains permanently open access under the terms of the Creative Commons Attribution License 4.0 International License

\begin{abstract}
The phase composition and structure of initial powders and the products of oxidation of aluminum alloys with calcium and barium containing 0.88 and 0.26 at.\% of dopants, respectively, have been studied for the first time by the diffraction method with the use of synchrotron radiation during programmed heating in air up to $1273 \mathrm{~K}$ at a rate of 10 $\mathrm{K} / \mathrm{min}$. It was established that as a result of the heterogeneity of the phase composition of the oxidation products and the structural changes in the oxide shell on the particle surface, aluminum oxide loses its high protective properties and metal oxidation is activated.
\end{abstract}

Keywords Aluminum Powders, Completeness of Oxidation, Alloying, In Situ Study of Structural Transformation

\section{Introduction}

Analysis of the physicochemical properties of aluminum-based alloys and the experimental data on their oxidation during programmed heating showed that structure heterogeneity of the metal core of the powders and the products of interaction on the surface contributes to the discontinuity of the barrier layer and increases the reactivity [1]. High segregation of $\mathrm{Ca}$ and $\mathrm{Ba}$ in the surface layers of aluminum-based alloy powders was established by XPS [2, 3].

Based on the results of these studies it was suggested that calcium and barium concentrate on the particle surface in the form of intermetallic compounds corresponding to aluminum-richest compositions $\left(\mathrm{Al}_{4} \mathrm{Ca}, \mathrm{Al}_{4} \mathrm{Ba}\right)$ on the phase diagrams of the investigated binary systems. The greatest influence on the heterogeneity of oxidation products on the surface of particles is exerted by surface-active metals. Concentrating in the surface layers, they activate the oxidation process. When the alloys transform into liquid state, the particle surface is enriched with a surface-active additive, which is present there in the structure of ordered microgroups corresponding to the most stable intermetallics, as shown in [4].

In [5], it was found that the intermetallic compounds in the structure of aluminum-based alloys play a leading role in the oxidation of powders, since they have higher reactivity with respect to atmospheric oxygen than aluminum.

Unfortunately, the traditional methods of analysis of the products formed during programmed heating in air do not allow one to track the kinetics and sequence of phase formation directly during the interaction [4]. That is why it is interesting to follow these processes in situ by the diffraction method with the use of synchrotron radiation, as shown in the works carried out in ISSCM SB RAS to study fast processes $[6,7]$.

In this work we studied experimentally the physical and chemical processes occurring during oxidation of aluminum-based powders doped with $\mathrm{Ca}$ and $\mathrm{Ba}$ in air.

\section{Experimental Section}

The examined powders of aluminum-based alloys with calcium and barium were obtained by spraying the melt with nitrogen. The metal content was $\sim 99 \%$. The specific surface area was measured on a Tristar 3000 v. 6.03 A device by thermal desorption of argon and amounted to $0.47 \mathrm{~m}^{2} / \mathrm{g}$ for spherically-shaped particles, which corresponds to the average particle diameter of about 5 microns. The content of calcium and barium in the powders was determined by mass spectrometry with inductively coupled plasma on an ELAN 9000 instrument to be 0.88 and 0.26 at.\%, respectively. The morphology of the particles was analyzed by means of a scanning Electron microscope JSM-6390 JEOL LA. In this work, we used the data of thermogravimetric studies of oxidation of powders in air obtained on a NETZSCH STA $409 \mathrm{PC} / \mathrm{PE}$ facility at a heating rate of $10 \mathrm{~K} / \mathrm{min}$. [2, 3].

The in situ studies of oxidation of the samples were carried out by X-ray diffraction using synchrotron radiation from the 
VEPP-3 station of Channel 4 on the basis of equipment available at ISSCM SB RAS [8].

Monochromatic radiation $(\lambda=0.308 \AA)$ passes through a thin layer of the sample and provides a diffraction pattern recorded by a flat two-dimensional detector. The detector is a system based on storage screens MAR345 (Marresearsh). The powder sample was placed into the hole of the aluminum oxide holder and heated in air at a rate of $10 \mathrm{~K} / \mathrm{min}$ up to $1273 \mathrm{~K}[8]$.

\section{Results and Discussion}

As a result of diffraction studies (Figure 1a) with the use of

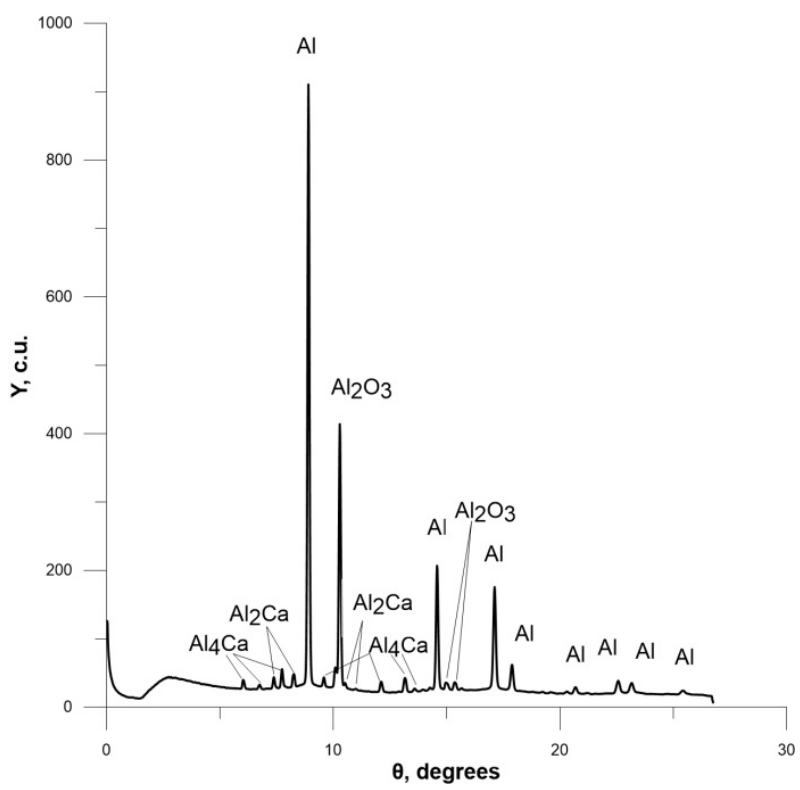

a) synchrotron radiation, it can be stated that the initial phase composition of the $\mathrm{Al}-\mathrm{Ca}$ alloy includes $\mathrm{Al}, \mathrm{Al}_{2} \mathrm{O}_{3}, \mathrm{Al}_{2} \mathrm{Ca}$ and $\mathrm{Al}_{4} \mathrm{Ca}$. This pattern persists up to the melting point, where the peaks are only displaced owing to an increase in the lattice parameters induced by thermal expansion. In case of the $\mathrm{Al}-\mathrm{Ba}$ alloy, the initial phase composition $\left(\mathrm{Al}, \mathrm{Al}_{4} \mathrm{Ba}\right.$, $\left.\mathrm{Al}_{2} \mathrm{O}_{3}\right)$ remains up to the eutectic melting point $(923 \mathrm{~K})$ (Figure 1b).

The amount of intermetallics found in the structure of the alloy powders is consistent with the equilibrium phase diagrams of the alloys $\mathrm{Al}-\mathrm{Ca}, \mathrm{Ba}$ [9].

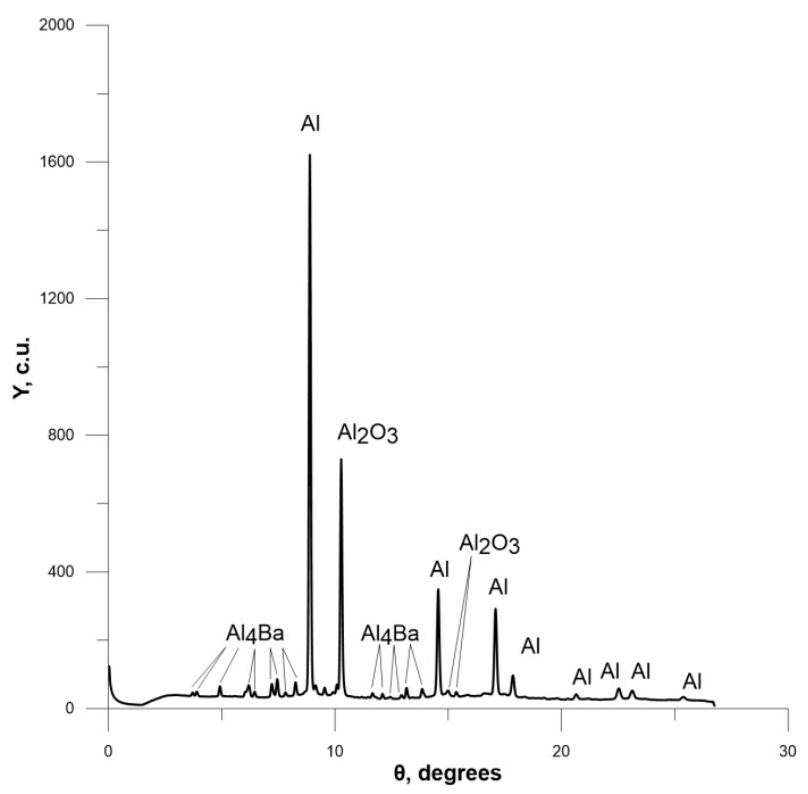

b)

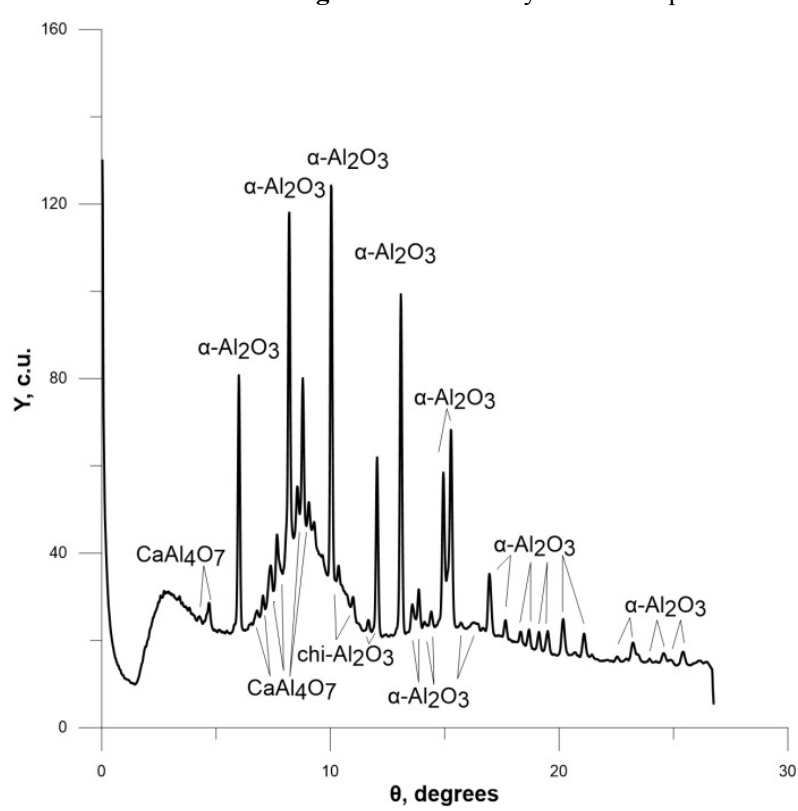

a)

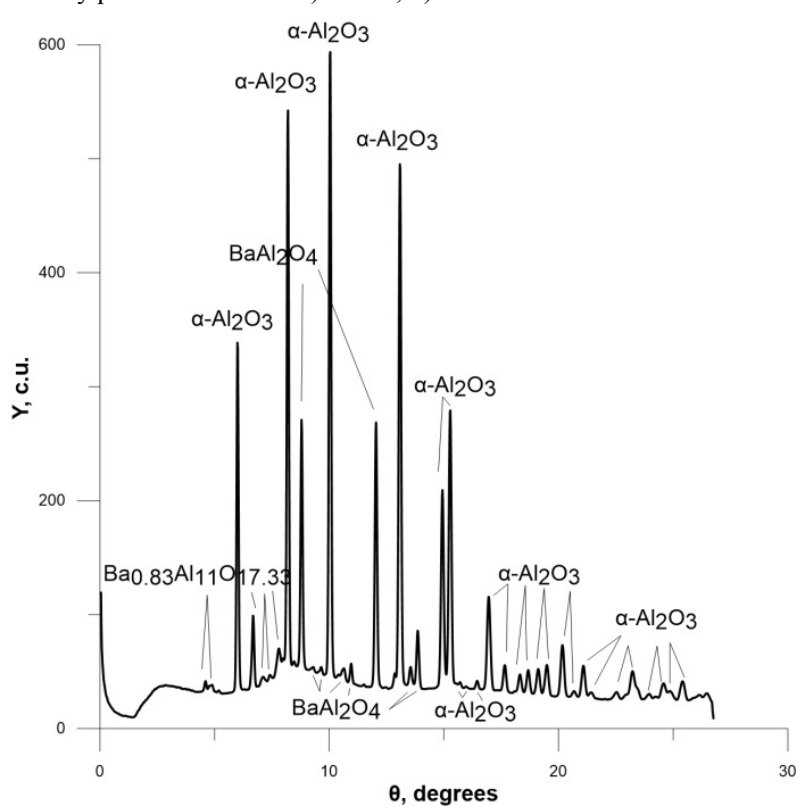

b)

Figure 2. The X-ray diffraction patterns of the alloy powder at $1273 \mathrm{~K}$ : a) Al-Ca; b) Al-Ba. 
After melting, the peaks of aluminum and intermetallics in the aluminum alloys with calcium disappear. Intensity maxima corresponding to $\mathrm{CaAl}_{4} \mathrm{O}_{7}$ and $\mathrm{Al}_{2} \mathrm{O}_{3}$ emerge. At $1273 \mathrm{~K}$, two modifications of alumina $\left(\alpha-\mathrm{Al}_{2} \mathrm{O}_{3}\right.$ and chi- $\mathrm{Al}_{2} \mathrm{O}_{3}$ ) and the double oxide $\mathrm{CaAl}_{4} \mathrm{O}_{7}$ are found in the $\mathrm{Al}-\mathrm{Ca}$ system (Figure 2a).

Upon the heating of the Al-Ba powder above the melting temperature, $\mathrm{Al}_{4} \mathrm{Ba}$ remains, and at further heating, in case of oxidation, two double oxides, $\mathrm{BaAl}_{2} \mathrm{O}_{4}$ and $\mathrm{Ba}_{0.83} \mathrm{Al}_{11} \mathrm{O}_{17.33}$, are formed and aluminum oxide is present in the form of $\alpha-\mathrm{Al}_{2} \mathrm{O}_{3}$ (Figure 2b).

The results of the thermogravimetric studies of the Al-Ca

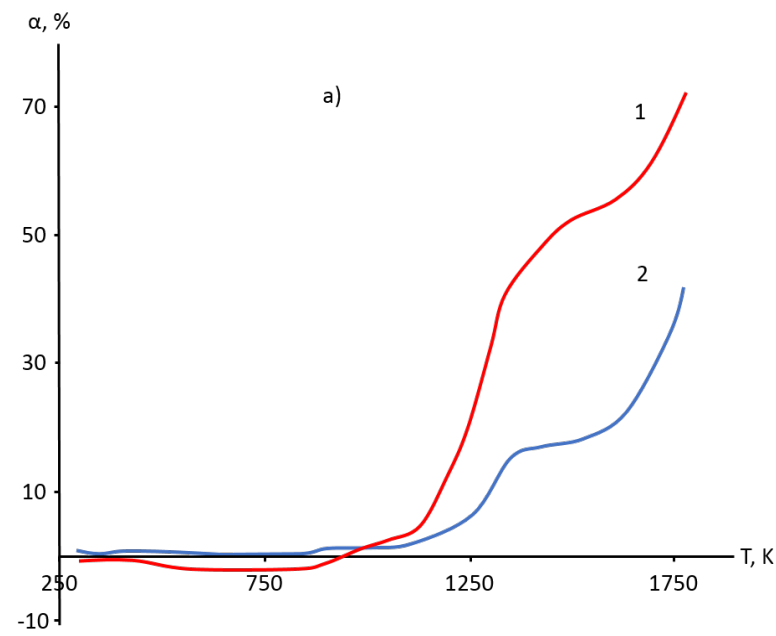

alloy powder (Figure 3) show [2] that the completeness of oxidation of the calcium alloy powder in the temperature range $1300-1550 \mathrm{~K}$ is at least twice as large as that of pure aluminum. Even at the maximum heating temperature, 1750 $\mathrm{K}$, the completeness of oxidation of the alloy powder is 1.65 times higher.

Comparison of the obtained results shows that the presence of four phases (alumina, two aluminum intermetallics and aluminum) in the structure of the initial alloy particles significantly changes the aluminum oxidation pattern. Beginning with $1000 \mathrm{~K}$, the oxidation process becomes very active.

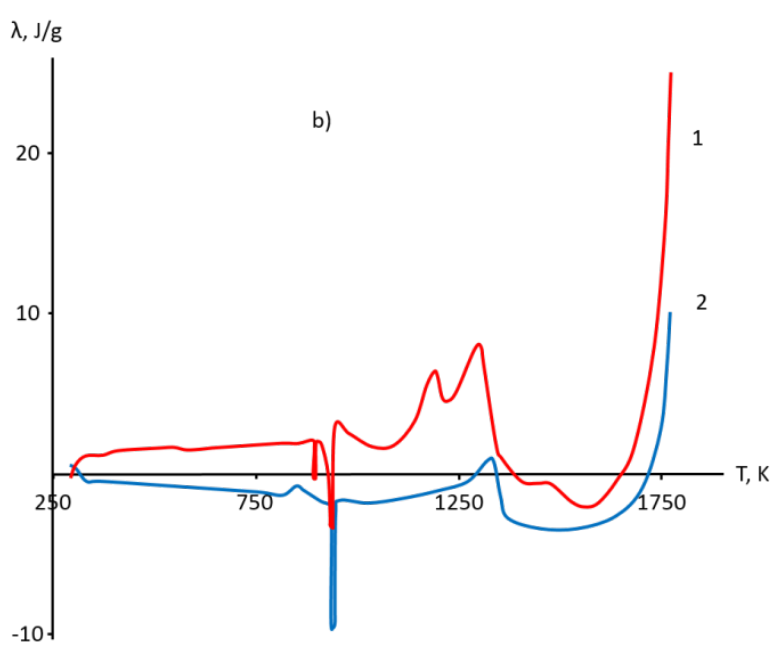

Figure 3. The TG (a) and DSC (b) curves: 1) - aluminum alloy with calcium; 2) pure aluminum; $\alpha$ - the completeness of oxidation.

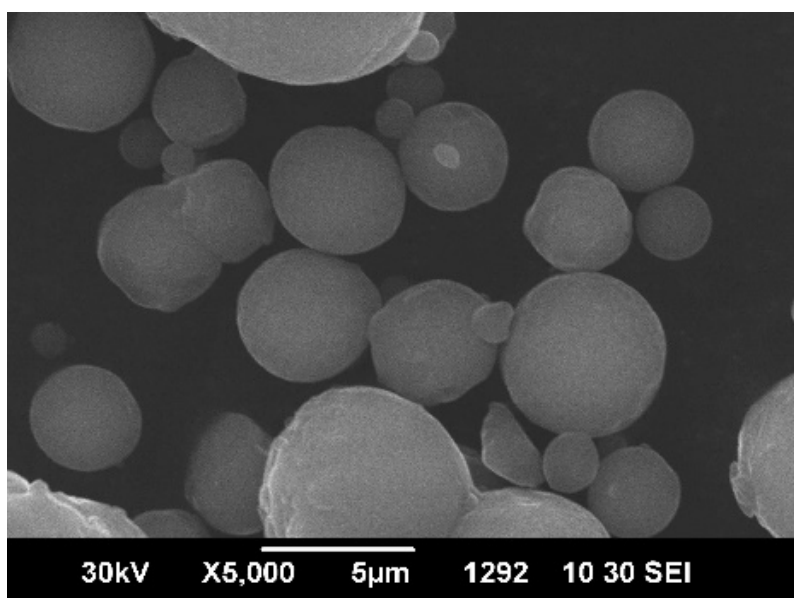

a)

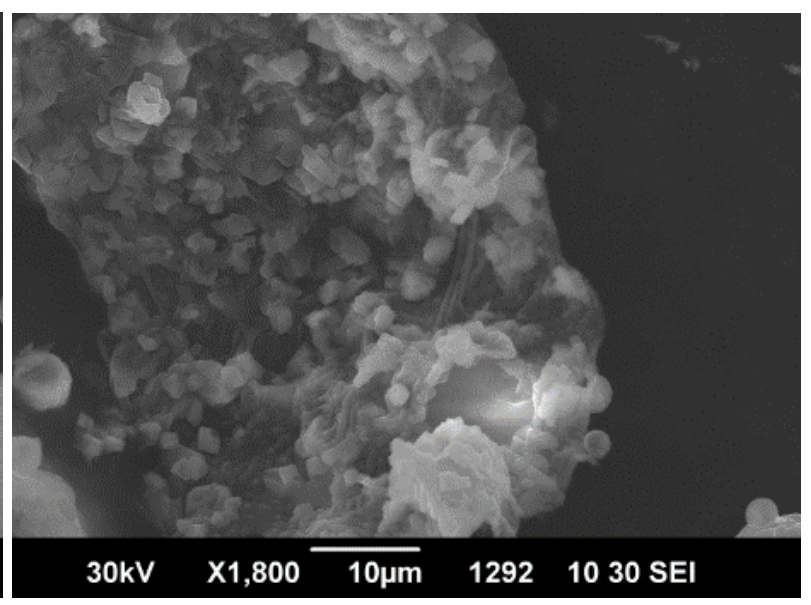

b)

Figure 4. The morphology of aluminum alloy powder with calcium: a) initial; b) oxidized at $1273 \mathrm{~K}$. 
The data of electron microscopy showed that active interaction changed the morphology of spherical precursor particles. From spherical particles they transformed into agglomerates of smaller particles of oxidation products of different shapes (Fig. 4). For barium aluminum alloy powder [3], the particle morphology changed significantly (Fig. 5). However, in this case the changes were not so considerable since the degree of conversion at $1273 \mathrm{~K}$ is much lower than for Al-Ca powder, and the oxidation process did not reach the active site interaction (Fig. 6).

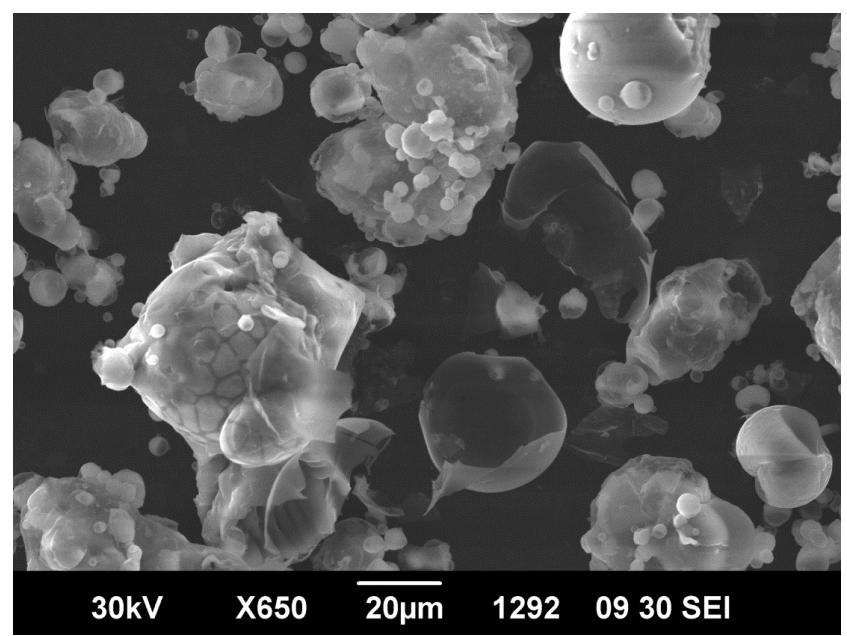

Figure 5. The particle morphology of Al-Ba powder oxidized during heating up to $1273 \mathrm{~K}$.

The obtained experimental results on $\mathrm{Ca}$ and $\mathrm{Ba}$ segregation on the surface of aluminum alloy powder particles, as well as the results of the study of phase formation during oxidation allow us to present a scheme of the interaction mechanism.

Figure 6 displays the curves of the transformation degree variation during oxidation of the powders and gives the regions of existence of phases present in the structure of the initial samples and formed during oxidation.

From Figure 6 it follows that the temperature intervals of active phase formation and the changes in the structure on the surface of particles and in the volume of the metal core correspond to the oxidation acceleration regions.

Table 1 shows some of the physical characteristics of the metallic and oxide phases in the structure and formed in the process of oxidation of the investigated aluminum alloy with calcium and barium.

where: $\mathrm{d}$ - the density of the metallic or oxide phase; $\mathrm{z}$ - the number of formula units; $\mathrm{n}$ - the number of metal atoms in the unit cell volume; $\mathrm{V}_{\mathrm{u}}$ - the volume of a unit cell; $\mathrm{V}$ - the molar volume; $\gamma$ - the molar ratio of volumes; $\Delta$ - the ratio of the comparison volumes of the obtained and the initial materials.

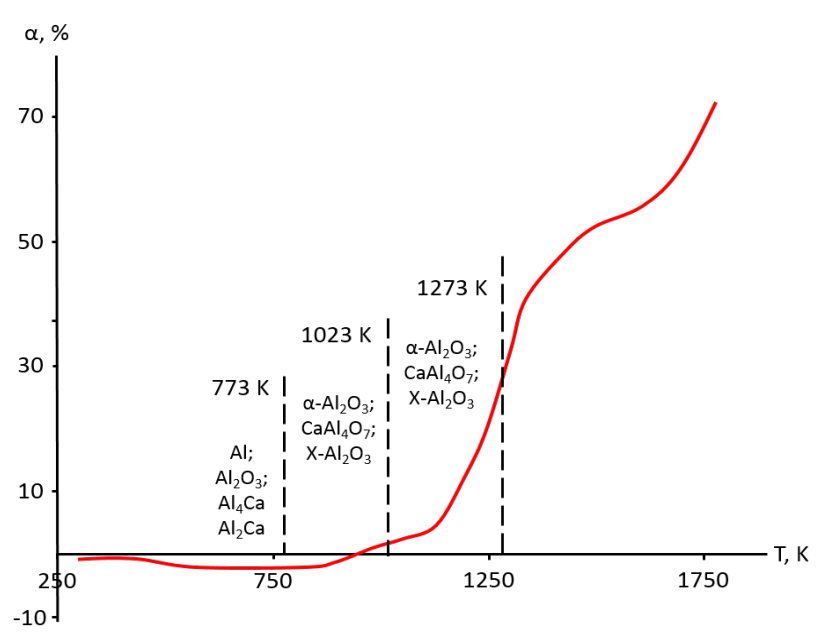

a)

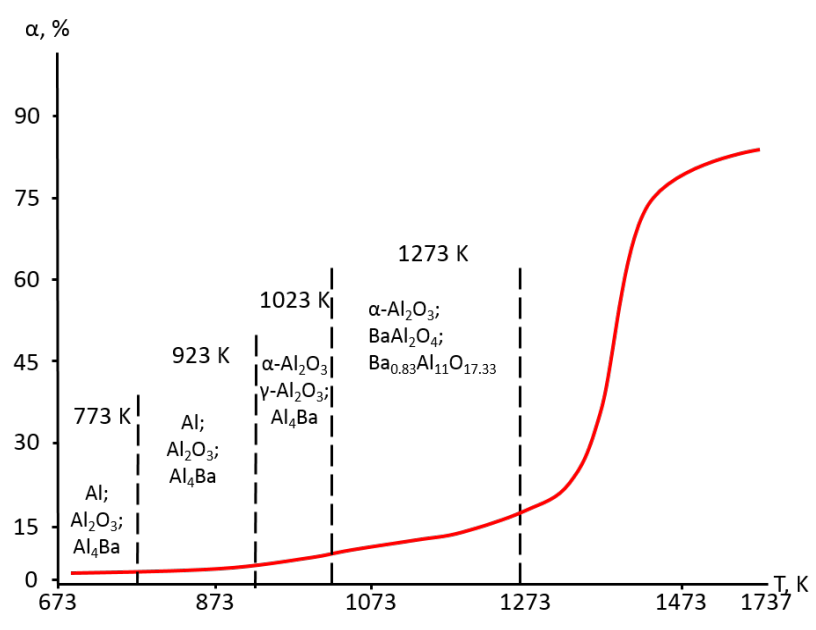

b)

Figure 6. The TG curves of alloys: a) Al-Ca; b) Al-Ba; $\alpha$ - the completeness of oxidation

From Table 1 follows that the formed double oxides have crystalline structures differ from the structure of the intermetallic compounds on the surface of which they form, and the structure of the individual oxides of the alloy components.

Thus, the primary cause of oxidation acceleration in the examined powders is continuous changing of the phase composition accompanied by structural changes in the oxidation product layer on the surface of particles of aluminum alloy powders with calcium and barium. The mechanism of the influence of $\mathrm{Ca}$ and $\mathrm{Ba}$ on the process of oxidation of disperse aluminum is explained by their high surface activity with respect to aluminum, which increases their concentration on the reaction surface of the powder, as well as the completeness and speed of the interaction because the barrier layer on the particle surface loses its protective properties. 
Table 1. The physical characteristics of the obtained phases

\begin{tabular}{|c|c|c|c|c|c|c|c|c|}
\hline $\begin{array}{l}\text { Metal, } \\
\text { oxide }\end{array}$ & $\mathrm{d}, \mathrm{g} / \mathrm{cm}^{3}$ & $\mathrm{z}$ & $\mathrm{n}$ & $\mathrm{V}_{\mathrm{u}}$ & V & $\gamma$ & $\Delta$ & The cell \\
\hline $\mathrm{Al}$ & 2.697 & 4 & 4 & 66.4 & 10 & - & - & $\begin{array}{c}\text { Cubic; } \\
\mathrm{a}=4.0494\end{array}$ \\
\hline$\gamma-\mathrm{Al}_{2} \mathrm{O}_{3}$ & 3.61 & 10.7 & 21.4 & 493.04 & 28.24 & 3.71 & 1.41 & $\begin{array}{c}\text { Cubic; } \\
\mathrm{a}=7.9\end{array}$ \\
\hline$\alpha-\mathrm{Al}_{2} \mathrm{O}_{3}$ & 3.98 & 6 & 12 & 279.6 & 25.62 & 0.28 & 0.91 & $\begin{array}{l}\text { Rhombohedral; } \\
\mathrm{a}=4.76 ; \mathrm{c}=12.99\end{array}$ \\
\hline $\mathrm{Al}_{2} \mathrm{Ca}$ & 2.405 & 8 & 24 & 519.33 & 39.1 & - & - & $\begin{array}{c}\text { Cubic; } \\
\mathrm{a}=8.038\end{array}$ \\
\hline $\mathrm{CaAl}_{4} \mathrm{O}_{7}$ & 2.88 & 4 & 20 & 546.27 & 90.28 & 0.21 & 1.38 & $\begin{array}{c}\text { Monoclinic; } \\
\mathrm{a}=12.94 ; \mathrm{b}=8.91 ; \mathrm{c}=5.446\end{array}$ \\
\hline $\mathrm{Al}_{4} \mathrm{Ca}$ & 2.329 & 2 & 10 & 211.01 & 63.55 & - & - & $\begin{array}{c}\text { Tetragonal; } \\
\mathrm{a}=4.362 ; \mathrm{c}=11.09\end{array}$ \\
\hline $\mathrm{CaAl}_{4} \mathrm{O}_{7}$ & 2.88 & 4 & 20 & 546.27 & 90.28 & 0.52 & 1.42 & $\begin{array}{c}\text { Monoclinic; } \\
\mathrm{a}=12.94 ; \mathrm{b}=8.91 ; \mathrm{c}=5.446\end{array}$ \\
\hline $\mathrm{Al}_{4} \mathrm{Ba}$ & 3.49 & 2 & 10 & 234.48 & 70.27 & - & - & $\begin{array}{c}\text { Tetragonal; } \\
\mathrm{a}=4.565 ; \mathrm{c}=11.252\end{array}$ \\
\hline $\mathrm{BaAl}_{2} \mathrm{O}_{4}$ & 4.094 & 2 & 6 & 208 & 62.36 & 0.3 & 1.48 & $\begin{array}{c}\text { Hexagonal; } \\
\mathrm{a}=5.218 ; \mathrm{c}=8.781\end{array}$ \\
\hline $\mathrm{Al}_{4} \mathrm{Ba}$ & 3.49 & 2 & 10 & 234.48 & 70.27 & - & - & $\begin{array}{c}\text { Tetragonal; } \\
\mathrm{a}=4.565 ; \mathrm{c}=11.252\end{array}$ \\
\hline $\mathrm{Ba}_{0.83} \mathrm{Al}_{11} \mathrm{O}_{17.33}$ & 3.72 & 2 & 22.166 & 617.03 & 184.96 & 0.24 & 1.19 & $\begin{array}{c}\text { Hexagonal; } \\
\mathrm{a}=5.587 ; \mathrm{c}=22.721\end{array}$ \\
\hline
\end{tabular}

In Fig. 7, four modifiers: $\mathrm{V}_{2} \mathrm{O}_{5} \cdot \mathrm{nH}_{2} \mathrm{O}$ and $\mathrm{NH}_{4} \mathrm{VO}_{3}+$ $\mathrm{HOCH}_{2} \mathrm{CH}_{2} \mathrm{OH}$ studied by authors [10,11], $\mathrm{Ca}$ and $\mathrm{Ba}$ are compared. It is seen that, depending on the type of modifier and the modification method, high completeness of oxidation were obtained. For example, for the more active powders the use of ethylene glycol is preferable.

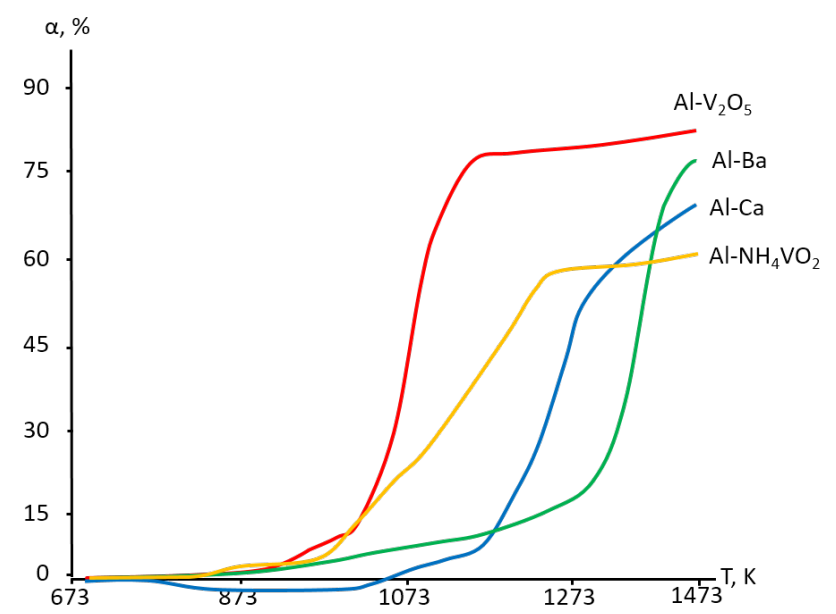

Figure 7. The TG curves of alloys: $\mathrm{Al}-\mathrm{V}_{2} \mathrm{O}_{5}, \mathrm{Al}-\mathrm{Ba}, \mathrm{Al}-\mathrm{Ca}, \mathrm{Al}-\mathrm{NH}_{4} \mathrm{VO}_{2} ; \alpha$ - the completeness of oxidation.

\section{Conclusions}

1. Using synchrotron radiation diffraction, we were the first to study the sequence of changes in the phase composition of the oxidation products on the surface and in the volume of powder particles based on aluminum alloys containing 0.88 at.\% $\mathrm{Ca}$ and 0.26 at.\% Ba directly during oxidation in air at a heating rate of $10 \mathrm{~K} / \mathrm{min}$.
2. It was established that the high reactivity of the dopants, along with surface activity with respect to aluminum (surface segregation), promotes oxidation activation.

3. It is shown that, the active oxidation areas of the powders correspond to the structural and phase rearrangements in the metal core of the particles and in the oxidation products on their surface.

\section{Acknowledgements}

This work was supported by the Russian Foundation for Basic Research (project 16-32-00061).

The part of the work relating to the measurement of spectra was done using the infrastructure of the Shared-Use Center "Siberian Synchrotron and Terahertz Radiation Center (SSTRC)" based on VEPP-3 of BINP SB RAS.

\section{REFERENCES}

[1] Effect of doping on the kinetics and mechanism of oxidation of aluminum-based alloy powders with rare and alkaline-earth metals / V. Shevchenko. - Russia, Novosibirsk: Fizika goreniya i vzryva (Physics of combustion and explosion), 2011. - V. 47. - No. 2. - P. 45-53. [in Russian]

[2] Surface segregation of calcium and its influence on the oxidation kinetics of aluminum-based alloy powders / V. Shevchenko, M. Kuznetsov, D. Eselevich [et al.] // Physical chemistry of surfaces and protection of materials, 2012. - V. 48. - No. 6. - P. 540-545.

[3] Surface activity of barium and its influence on the reactivity of aluminum-based powder / V. Shevchenko, M. Kuznetsov, A. 
Konyukova [et al.] // Physical chemistry of surfaces and protection of materials, 2013. - V. 49. - No. 6. - P. 1-5.

[4] Physical chemistry of activation of disperse systems based on aluminum / V. Kononenko, V. Shevchenko. - Russia, Ekaterinburg, Ural Branch of the Russian Academy of Sciences, 2006. - 238 p. [in Russian]

[5] The role of intermetallic compounds in the oxidation of powders of the systems Al-REM / V. Shevchenko, I. Latosh, I. Grigorov [et al.]. - Russia, Yekaterinburg: Rasplavy (Melts), 2009. - No. 3. - P. 60-68. [in Russian]

[6] Preparation of $\mathrm{CuO}-\mathrm{CeO}_{2}$ catalysts deposited onto the glass fiber surface by self-propagating thermosynthesis / I. Desyatykh, A. Vedyachin, Y. Kitopevich, P. Tsyrulnikov. Russia, Novosibirsk: Fizika goreniya i vzryva (Physics of combustion and explosion), 2011. - V. 47. - No. 6. - P. 68-74. [in Russian]

[7] Experience in application of synchrotron radiation for studying detonation processes / V. Titov, E. Prudep, K. Ten [et al.] // Physics of combustion and explosion, 2011. - V. 47. - No. 6. - P. 3-15.

[8] New station at the $4^{\text {th }}$ beamline of the VEPP-3 storagering / A. Ancharov, A. Manakov, N. Mezentsev [et al.] // Nucl. Inst. Meth. A. - 2001. - V. 470. - No. 12. - P. 80-83.

[9] The phase diagrams of binary metal systems: Reference Book in 3 volumes: Vol. 1 / P. Lyakisheva. - Russia, Moscow: Mashinostroyeniye, 1997. - 992 P. [in Russian].

[10] Effect of $\mathrm{V}_{2} \mathrm{O}_{5}$ powder on the oxidation mechanism of ASD-4 / V. Shevchenko, V. Krasilnikov, D. Eselevich [et al.] // Physics of combustion and explosion, 2015. - V. 51. - № 5. - P. $572-577$.

[11] Investigation of influence $\mathrm{NH}_{4} \mathrm{VO}_{3}+\mathrm{HOCH}_{2} \mathrm{CH}_{2} \mathrm{OH}$ oxidation of ASD-4 powder / V. Shevchenko, D. Eselevich, V. Krasilnikov [et al.]. // Physics Procedia, 2016. - V. 84. - P. 330-336. 